\author{
ГЕОХИМИЯ НАФТИДОВ ИЗ ЛОКАЛИЗОВАННЫХ НА СУШЕ \\ ГИДРОТЕРМАЛЬНЫХ ИСТОЧНИКОВ И ВОПРОСЫ ИХ ГЕНЕЗИСА \\ (Узон, Йеллоустоун, Новая Зеландия) \\ Е.А. Фурсенко ${ }^{1,2}$, В.А. Каширцев ${ }^{1,2}$, А.Э. Конторович ${ }^{1,2}$, А.Н. Фомин ${ }^{1,2}$ \\ ${ }^{1}$ Институт нефтегазовой геологии и геофизики им. А.А. Трофимука СО РАН, \\ 630090, Новосибирск, просп. Академика Коптюга, 3, Россия \\ ${ }^{2}$ Новосибирский государственньй университет, 630090, Новосибирск, ул. Пирогова, 2, Россия
}

\begin{abstract}
Систематизирована и с единых позиций проанализирована информация о нафтидопроявлениях в зонах активной гидротермальной деятельности и современного вулканизма на суше (нафтиды источников кальдеры влк. Узон, Национального парка Йеллоустоун и Новой Зеландии), определены черты их сходства и различия. Установлено, что гидротермальные нафтиды образовались за счет липидов разного по природе живого вещества: фитопланктон, бактериальные сообщества, археи, а также остатки высшей наземной растительности, в том числе споры, пыльца и т.п., которые могли попадать в осадок эоловым путем.

Гидротермальные нафтиды различаются уровнем зрелости, но в целом они менее преобразованы, чем большинство бассейновых нефтей. Особенности состава гидротермальных нафтидов (групповой состав, характер распределения $H$-алканов) свидетельствуют также о воздействии на них процессов гипергенеза (потеря легких фракций, окисление и биодеградация).
\end{abstract}

Гидротермальная нефть, бассейновая нефть, органическая геохимия, углеводороды-биомаркеры, Узон, Йеллоустоун, Новая Зеландия.

\title{
NAPHTHIDES OF CONTINENTAL HYDROTHERMS (Uzon, Yellowstone, New Zealand): GEOCHEMISTRY AND GENESIS
}

\section{E.A. Fursenko, V.A. Kashirtsev, A.E. Kontorovich, and A.N. Fomin}

We summarize and analyze the available data on naphthide shows in continental zones of active hydrothermal and modern volcanic activity (Uzon Volcano caldera, Yellowstone National Park, and New Zealand springs) and examine their similarity and difference. The analysis demonstrated that hydrothermal naphthides formed from lipids of living matter of different nature: phytoplankton, bacterial communities, archaea, and remains of higher land plants, including spores and pollen, which might have been supplied to the sediment through eolian transportation.

Hydrothermal naphthides are different in the degree of maturity, but in general they are less transformed than most of basin oils. Their group composition and distribution of $n$-alkanes evidence that they were subject to hypergenesis, which led to the loss of light fractions, oxidation, and biodegradation. Zealand

Hydrothermal oil, basin oil, organic geochemistry, hydrocarbon biomarkers, Uzon, Yellowstone, New

\section{ВВЕДЕНИЕ}

Природа и химия нафтидопроявлений, которые установлены в ряде районов с активной гидротермальной деятельностью на Земле, привлекают интерес исследователей во всем мире. Имеются данные, что их образование является быстрым (первые тысячи лет - десятки лет), почти мгновенным по геологическим меркам, процессом термолизной, а в отдельных случаях и термокаталитической переработки органического вещества (ОВ) за счет энергии гидротермальных систем [Бескровный, Лебедев, 1971; Калинко, 1975; Simoneit, Lonsdale, 1982; Kawka, Simoneit, 1987; Карпов, 1988; Brault et al., 1988; Kvenvolden, Simoneit, 1990; Simoneit, 1993; Bazhenova et al., 1998; Simoneit et al., 2009; Конторович и др., 2011; и др.]. Подобные нафтидопроявления по составу и условиям генерации являются уникальными природными образованиями. Большинство из них установлено в осадках и наддонных водах гидротермально активных зон Мирового океана. Известны единичные находки нафтидопроявлений в зонах активной гидротермальной деятельности и современного вулканизма на суше: кальдера влк. Узон (п-ов Камчатка, Россия), Национальный парк Йеллоустоун (США), Новая Зеландия (рис. 1). 


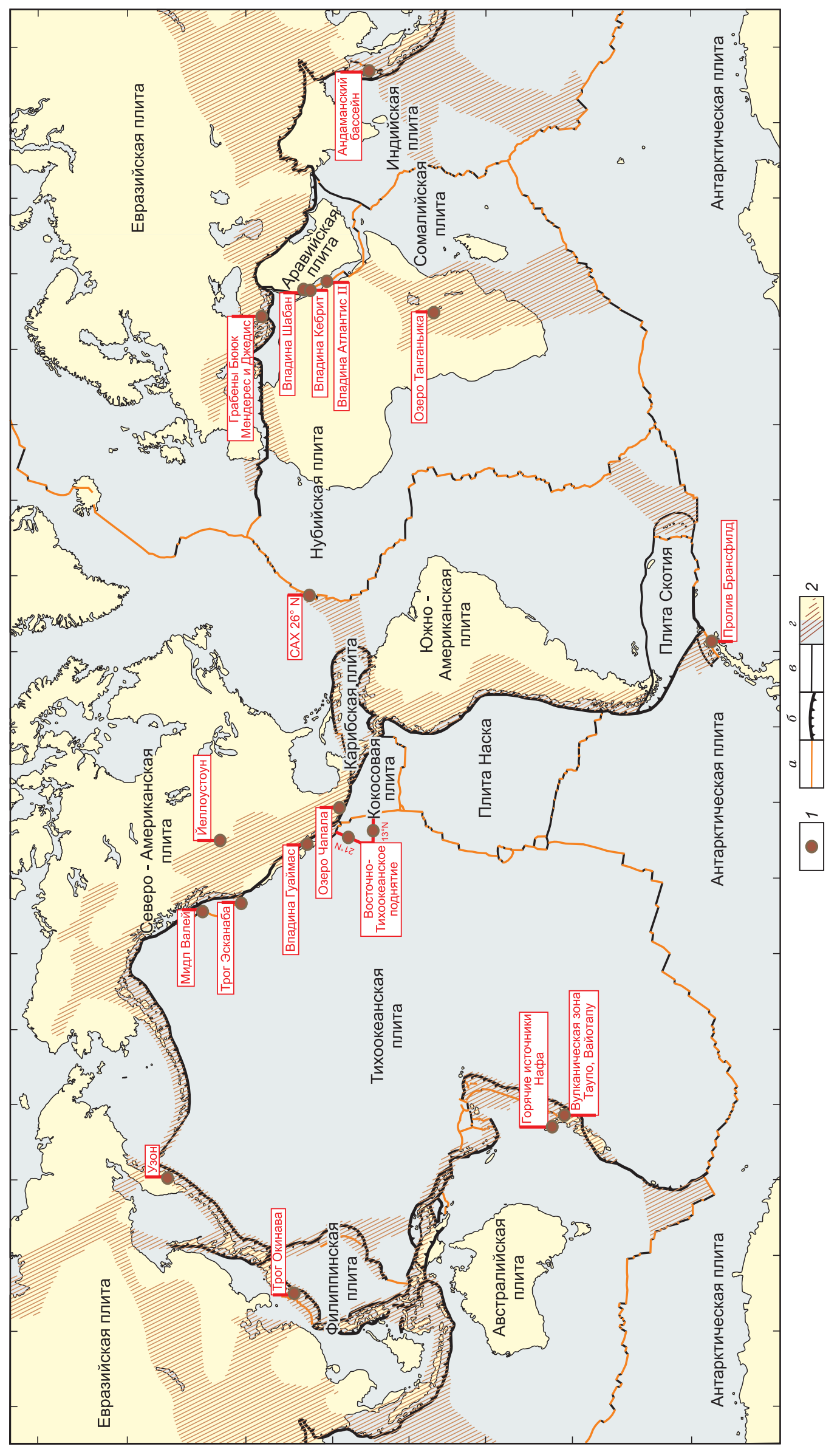

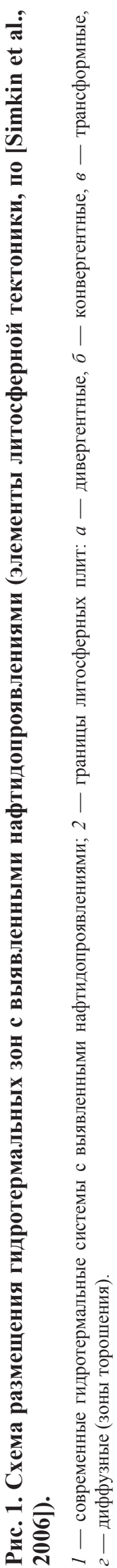


В работе на основе систематизации и сравнительного анализа информации по составу нафтидов в зонах активной гидротермальной деятельности и современного вулканизма на суше определены основные черты их сходства и различия. Это дает новую ценную информацию об источниках и условиях генерации углеводородных (УВ) флюидов в таких зонах.

Для точности последующего изложения уточним терминологию.

Как известно, Н.А. Орлов и В.А. Успенский [Орлов, Успенский, 1936; Успенский и др., 1964] предлагали различать нафтиды и нафтоиды. По определению В.А. Успенского, нафтоиды - особая генетическая ветвь природных битумов, представляющих собой продукт термической деструкции ОВ в условиях контактового метаморфизма и катагенеза. Согласно этому определению, нафтоиды отличаются от нафтидов источником тепловой энергии для преобразования ОВ и скоростью реакций при этих преобразованиях. Расширяя толкование предложенного В.А. Успенским термина (тепло не только контактового метаморфизма и катагенеза, но и гидротерм), можно называть гидротермальные нефти нафтоидами. Недостаток этого термина - отсутствие аналогов в английском и других языках с развитой научной понятийной и терминологическими базами. Видимо, ощущая этот недостаток, авторы «Горной энциклопедии» (М.В. Дахнова) предложили перевод этого термина на ряд языков: английский naphthoids, немецкий — Naphtoide, французский — naphtoides, испанский — naftoides, naphtoides. Однако, по нашим наблюдениям, эти термины в научной литературе практически не используются.

В соответствии с традициями современной российской и англоязычной научной геологической литературы будем различать процессы нефтегазообразования в результате термокаталитических превращений липидов ОВ в осадочных бассейнах по мере погружения нефтепроизводящих пород и в зонах интрузивной и гидротермальной деятельности. Первый тип нафтидогенеза будем называть бассейновым, второй — контактовым, третий - гидротермальным. Соответственно нефти будем называть бассейновыми, зон контактового метаморфизма и катагенеза и гидротермальными.

\section{МАТЕРИАЛ И МЕТОДИКИ ИССЛЕДОВАНИЯ}

Геохимия узонской нефти (п-ов Камчатка) обсуждалась в разные годы в работах [Бескровный, Лебедев, 1971; Калинко, 1975; Карпов, 1988; Bazhenova et al., 1998; Simoneit et al., 2009; Конторович и др., 2011]. В этой статье для сравнительного анализа использована информация о составе двух проб капельно-жидкой нефти, отобранных А.Н. Фоминым и Е.А. Фурсенко и проанализированных в ИНГГ СО РАН. Пробы отбирали с поверхности воды в шурфах на нефтяной площадке Центрального термального поля кальдеры влк. Узон в ходе экспедиционных работ в 2007 и 2012 гг. Подробно условия отбора проб описаны в перечисленных выше работах.

Таблица 1 .

Методы исследования

\begin{tabular}{|c|c|c|c|c|c|c|c|}
\hline \multirow{3}{*}{$\begin{array}{c}\text { Локализация нафтидо- } \\
\text { проявления }\end{array}$} & \multicolumn{4}{|c|}{ Исследование структурно-группового состава } & \multicolumn{3}{|c|}{$\begin{array}{l}\text { Исследование распределения УВ- } \\
\text { биомаркеров насыщенной фракции }\end{array}$} \\
\hline & \multirow{2}{*}{$\begin{array}{c}\text { Высаживание } \\
\text { асфальтенов } \\
\text { (раствори- } \\
\text { тель) }\end{array}$} & \multicolumn{3}{|c|}{$\begin{array}{c}\text { Жидкостная хроматография (насыщенная, } \\
\text { ароматическая и полярная фракции) }\end{array}$} & \multirow{2}{*}{$\begin{array}{c}H \text {-алканы и } \\
\text { ациклические } \\
\text { изопренаны }\end{array}$} & \multirow{2}{*}{ Стераны } & \multirow{2}{*}{ Терпаны } \\
\hline & & $\begin{array}{l}\text { Вид хромато- } \\
\text { графии }\end{array}$ & Сорбенты & Элюэнты & & & \\
\hline Узон, Камчатка & $\begin{array}{l}\text { Петролейный } \\
\text { эфир }\end{array}$ & Колоночная & $\begin{array}{c}\text { Сели- } \\
\text { кагель, } \\
\mathrm{Al}_{2} \mathrm{O}_{3} \\
\end{array}$ & $\begin{array}{c}\text { Петролейный } \\
\text { эфир, бензол, } \\
\text { этиловый спирт }\end{array}$ & $\begin{array}{c}\text { ГЖХ; ХМС } \\
\text { насыщенной } \\
\text { фракции }\end{array}$ & $\begin{array}{c}\text { XMC } \\
m / z 217 \\
218\end{array}$ & $\begin{array}{c}\mathrm{XMC} m / z \\
191,177\end{array}$ \\
\hline $\begin{array}{l}\text { Кальцитовые источники, } \\
\text { Йеллоустоун }\end{array}$ & \multirow{2}{*}{ Гексан } & \multirow{2}{*}{$\begin{array}{l}\text { Высокоэффек- } \\
\text { тивная, препа- } \\
\text { ративная }\end{array}$} & \multirow{2}{*}{$»$} & \multirow{2}{*}{ Толуол, метанол } & $\begin{array}{l}\text { ГЖХ насыщен- } \\
\text { ной фракции }\end{array}$ & \multirow{4}{*}{$\begin{array}{c}\text { XMC } \\
m / z 217\end{array}$} & \multirow{4}{*}{$\begin{array}{c}\mathrm{XMC} m / z \\
191\end{array}$} \\
\hline $\begin{array}{l}\text { Радужные источники, } \\
\text { Йеллоустоун }\end{array}$ & & & & & ГЖХ нефти & & \\
\hline $\begin{array}{l}\text { Вайотапу, Новая Зелан- } \\
\text { дия }\end{array}$ & \multirow{2}{*}{ Пентан } & \multirow{2}{*}{$\gg$} & \multirow{2}{*}{$\gg$} & \multirow{2}{*}{$\begin{array}{c}\text { Гексан, то- } \\
\text { луол-гексан, } \\
\text { метиленхлорид- } \\
\text { метанол }\end{array}$} & \multirow{2}{*}{ ГЖX* } & & \\
\hline Нафа, Новая Зеландия & & & & & & & \\
\hline
\end{tabular}

Примечание. ГЖК - газожидкостная хроматография, ХМС - хромато-масс-спектрометрия.

* Для выделения из насыщенной фракции $н$-алканов и изоалканов применялись молекулярные сита типа $5 \AA$ (цеолит СаX) и образования комплексов с мочевиной [Czochanska et al., 1986; Weston, Woolhouse, 1987]. 
B pаботе [Clifton et al., 1990] обсуждаются два местонахождения нафтидов в Национальном парке Йеллоустоун (США). Это насыщенные нефтеподобным веществом блоки кристаллов серы и почвы в районе Кальцитовых источников и нефтепроявления парогазовых выходов Радужных источников. Нафтидопроявления, локализованные в зонах распространения современных гидротерм в Новой Зеландии, исследованы в районах Вайотапу (вулканическая зона Таупо) [Czochanska et al., 1986] и Нафа (северозапад Северного острова) [Weston, Woolhouse, 1987].

Аналитическое исследование состава гидротермальных нафтидов проводилось близкими методами (табл. 1). Нафтиды из почв и блоков кристаллов серы Кальцитовых источников Йеллоустоуна (3 пробы) экстрагировались смесью метиленхлорида $\left(\mathrm{CH}_{2} \mathrm{Cl}_{2}\right)$ и метанола [Clifton et al., 1990]. Из нефтей Новой Зеландии перед хроматографированием на колонке с активированной медью была удалена элементарная сера [Czochanska et al., 1986; Weston, Woolhouse, 1987]. Узонские нефти (2 пробы) перед анализом были высушены при помощи $\mathrm{CaCl}_{2}$.

Для сравнительной характеристики геохимии нафтидов использовалась информация об их структурно-групповом составе, распределении $\boldsymbol{H}$-алканов и ациклических изопренанов, стеранов и терпанов в насыщенной фракции, полученная методами жидкостной хроматографии, газовой хроматографии и хромато-масс-спектрометрии (см. табл. 1).

\section{СОСТАВ ГИДРОТЕРМАЛЬНЫХ НАФТИДОВ}

Информация о групповом и УВ-составе гидротермальных нафтидов, который довольно разнообразен, систематизирована в табл. 2. В соответствии со структурно-групповым составом рассматриваемых нафтидов в дальнейшем будем пользоваться классификацией, принятой в российской геологии нефти и газа [Успенский и др., 1964; Геология..., 1981]. Нафтид из Радужных источников Йеллоустоунского парка по условиям отбора (из парогазовых выходов) и составу (4.3\% смол и асфальтенов) следует классифицировать как конденсат. На конденсатную природу этого нафтидопроявления указывает также высокая концентрация насыщенных УВ (83.8\%). Нафтидопроявления кальдеры влк. Узон на Камчатке являются тяжелыми (плотность $>880$ кг $/ \mathrm{M}^{3}$ ) малосмолистыми нефтями: они содержат 10$13 \%$ гетероциклических соединений, из них асфальтенов менее $0.3 \%$, а насыщенных УВ почти в два раза больше, чем ароматических (см. табл. 2). Нафтидопроявление района Вайотапу (Новая Зеландия) представляет собой смолистую нефть. Она содержит 31.7 \% гетероциклических соединений, в том числе $1.7 \%$ асфальтенов. В ней в составе УВ преобладают ароматические соединения (42.7 против $25.6 \%$ насыщенных УВ). Наконец, нафтиды Кальцитовых источников Йеллоустоуна являются мальтами. Концентрация смол и асфальтенов в них варьирует от 49.5 до $72.8 \%$. Отличительной особенностью этих мальт является существенно ароматический УВ состав, а насыщенные соединения составляют менее $1 \%$ от фракции УВ.

В гидротермальных нефтях, так же как и в их бассейновых аналогах, идентифицирован широкий спектр УВ: $н$-алканы, ациклические изопренаны, цикланы и арены [Добрянский, 1948; Вассоевич, 1958; Успенский и др., 1964; Тиссо, Вельте, 1981; Петров, 1984; Peters et al., 2005].

$H$-алканы в рассматриваемых нафтидах представлены гомологическим рядом от $\mathrm{C}_{11}$ до $\mathrm{C}_{33}$. $\mathrm{B}$ нефти из кальдеры Узон и в конденсате Радужных источников в максимальной концентрации присутствует $\mu$-алкан $\mathrm{C}_{18}$. В нефти из района Нафа (Новая Зеландия) максимум концентраций $\boldsymbol{t}$-алканов смещен в

Таблица 2 Групповой и углеводородный состав гидротермальных нафтидов

\begin{tabular}{l|c|c|c|c|c}
\hline \multirow{2}{*}{$\begin{array}{c}\text { Локализация нафтидопро- } \\
\text { явления }\end{array}$} & \multicolumn{3}{|c|}{ Углеводороды, \% } & Смолы и асфальтены, \% & $\begin{array}{c}\text { Насыщенные УВ/арома- } \\
\text { тические УВ }\end{array}$ \\
\cline { 2 - 5 } Узон, Камчатка & насыщенные & ароматические & Сумма & & 1.77 \\
& 57.49 & 32.51 & 90.00 & 10.00 & 1.89 \\
Кальцитовые источники, & 56.88 & 30.13 & 87.01 & 49.51 & 0.02 \\
Йеллоустоун & 0.99 & 49.50 & 50.49 & 72.80 & 0.03 \\
Радужные источники, & 0.80 & 26.40 & 27.20 & 69.21 & 0.02 \\
Йеллоустоун & 83.80 & 30.20 & 30.79 & 4.30 & 7.04 \\
Вайотапу, Новая Зеландия & 25.60 & 11.90 & 95.70 & 31.70 & 0.60
\end{tabular}

Примечание. Информация о групповом и углеводородном составе нафтидов Йеллоустоуна и Новой Зеландии приведена по работам [Czochanska et al., 1986; Clifton et al., 1990]. 

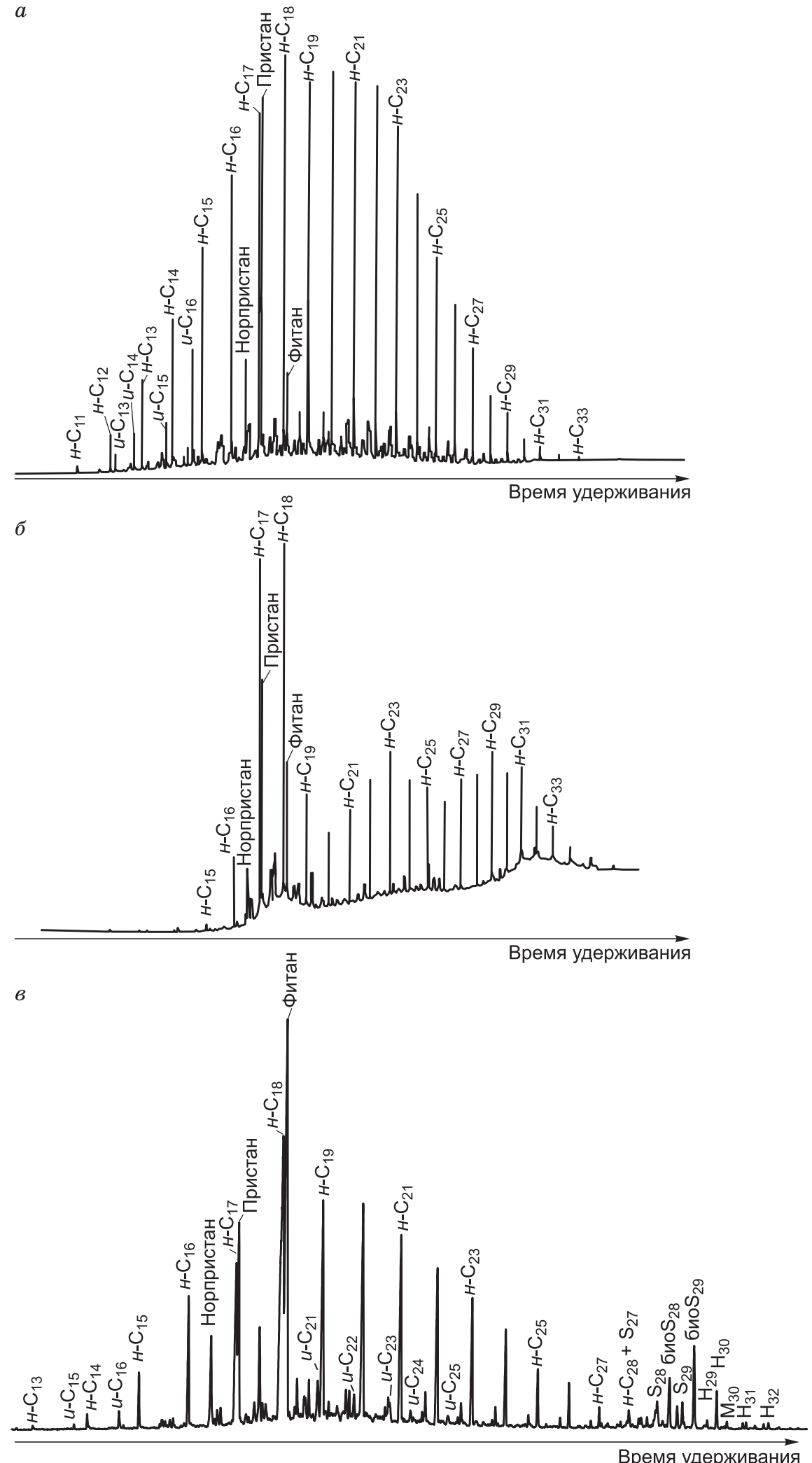

Рис. 2. ГЖХ-хроматограммы конденсата Радужных источников ( $a$ ) и насыщенных фракций мальты Кальцитовых источников (б) (Йеллоустоун), по [Clifton et al., 1990]; нефти кальдеры влк. Узон (Камчатка) (в).

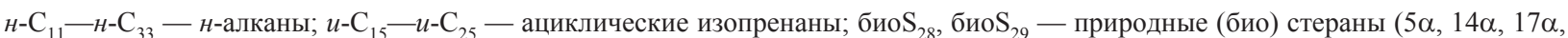

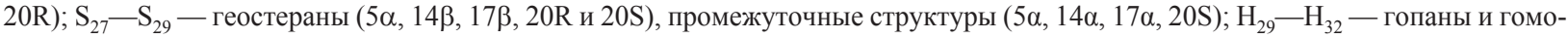

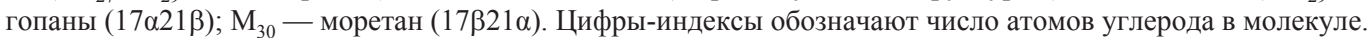


Таблица 3 .

Параметры по составу н-алканов и ациклических изопренанов

\begin{tabular}{|c|c|c|c|c|}
\hline Локализация нафтидопроявления & Пристан/фитан & Пристан $/ \mu-\mathrm{C}_{17}$ & Фитан $/ н-\mathrm{C}_{18}$ & $\mathrm{CPI}$ \\
\hline \multirow{2}{*}{ Узон, Камчатка } & 0.46 & 0.98 & 1.00 & 0.89 \\
\hline & 0.49 & 1.22 & 1.41 & 0.98 \\
\hline Кальцитовые источники, Йеллоустоун & $1.61^{*}$ & $0.69 *$ & $0.36^{*}$ & $1.16^{*}$ \\
\hline Радужные источники, Йеллоустоун & $4.39 *$ & $1.05^{*}$ & $0.20 *$ & $1.15^{*}$ \\
\hline Вайотапу, Новая Зеландия & 0.64 & 1.06 & 2.37 & $\approx 1.00$ \\
\hline Нафа, Новая Зеландия & 1.92 & 0.66 & 0.23 & 1.00 \\
\hline
\end{tabular}

* Рассчитано авторами по высотам пиков в спектрах, опубликованных в работе [Clifton et al., 1990]. CPI — коэффициент нечетности для $н$-алканов состава $\mathrm{C}_{25}-\mathrm{C}_{34}$, по [Bray, Evans, 1961].

высокомолекулярную область - на $\mathrm{C}_{21}$. В нефти Вайотапу (Новая Зеландия) и мальтах Кальцитовых источников имеет место несколько максимумов в распределении $\mathrm{H}$-алканов $\left(\mathrm{C}_{16}, \mathrm{C}_{22}\right.$ и $\mathrm{C}_{18}, \mathrm{C}_{23}, \mathrm{C}_{29}$ соответственно). Соотношение концентраций $\mu$-алканов с нечетным и четным количеством атомов углерода в молекуле в большинстве исследованных нафтидов близко к 1. Только в мальтах Кальцитовых источников высокомолекулярных $\mu$-алканов с нечетным количеством атомов углерода больше, чем с четным. Это выражается в пилообразном характере их распределения (рис. 2) и, как следствие, в высоких значениях индекса СРІ (табл. 3).

Среди ациклических изопренанов в гидротермальных нафтидах, как и в бассейновых нефтях, в максимальных концентрациях находятся пристан, фитан, а также норпристан (см. рис. 2). Отношение пристан/фитан варьирует в широких пределах — от 0.46 до 4.39. В нефтях Узона и Вайотапу (Новая Зеландия) содержания пристана и фитана одинаковы или несколько выше концентраций $\mu$-алканов, близких им по времени выхода при ГЖХ-анализе $\left(\mathrm{C}_{17}\right.$ и $\mathrm{C}_{18}$ соответственно). В остальных нефтях концентрации $н$-алканов $\mathrm{C}_{17}$ и $\mathrm{C}_{18}$ существенно выше, чем соответствующих алифатических изопренанов.

В составе фракций насыщенных УВ гидротермальных нафтидов идентифицированы стераны состава $\mathrm{C}_{27}-\mathrm{C}_{29}$. Как видно на масс-фрагментограммах при $m / z 217$ (рис. 3) насыщенной фракции нефтей Узона и Новой Зеландии, в них повышены содержания «биологических» структур $(5 \alpha, 14 \alpha, 17 \alpha, 20 \mathrm{R}$ стераны), наследующих стереохимию стероидов живого вещества. Соотношение стеранов $\mathrm{C}_{27}-\mathrm{C}_{29}$ варьирует в широких пределах. Так, в конденсате Радужных источников из гомологов стеранов идентифицированы только этилхолестаны. В нефтях Узона и Вайотапу среди стеранов максимально содержание этилхолестана $\left(\mathrm{C}_{29}\right)$. В нефти Нафа (Новая Зеландия) в наибольшей концентрации идентифицирован холестан $\left(\mathrm{C}_{27}\right)$, а содержание этилхолестана $\left(\mathrm{C}_{29}\right)$ и метилхолестана $\left(\mathrm{C}_{28}\right)$ несколько ниже. В мальтах Кальцитовых источников в максимальной концентрации также находится холестан.

В мальтах Кальцитовых источников концентрации диастеранов сопоставимы с регулярными стеранами [Clifton et al., 1990]. Сходным распределением стеранов и диастеранов характеризуется нефть источников Нафа. В узонской нефти диастеранов мало (см. рис. 3).

Согласно работе [Clifton et al., 1990], наиболее интенсивные пики на масс-фрагментограмме при $m / z 217$ насыщенной фракции конденсата Радужных источников указывают на высокие концентрации в нем негопаноидных пентациклических терпанов - бикадинана и его изомеров (см. рис. 3). Эти же углеводороды идентифицированы на масс-фрагментограммах терпанов ( $/ \mathrm{z} 191)$ (рис. 4).

По масс-фрагментограммам терпанов $(m / z$ 191) насыщенных фракций в составе гидротермальных нафтидов идентифицированы трициклические терпаны - хейлантаны, тетрациклические терпаны, норгопаны, гопан и гомогопаны, а также моретаны (см. рис. 4). В нафтидах Йеллоустоуна и Вайотапу по сравнению с узонской нефтью значительно выше концентрации трицикланов. Особенностью терпановых УВ из мальт Кальцитовых источников и нефтей Нафа является присутствие $\beta \beta$ гопанов - нестабильных промежуточных продуктов преобразования гопаноидных структур живого вещества [Петров, 1984; Peters et al., 2005].

Помимо полициклических УВ-биомаркеров (стераны и терпаны) в узонской нефти [Конторович и дp., 2011] и конденсате Радужных источников [Clifton et al., 1990] идентифицированы алкилциклогексаны состава $\mathrm{C}_{18}-\mathrm{C}_{23}$, биологическими предшественниками которых считаются ненасыщенные жирные кислоты и/или каротиноидные спирты, биологическим источником которых может быть фитопланктон [Peters et al., 2005].

Анализ состава ароматической фракции из мальт Кальцитовых источников показал [Clifton et al., 1990], что они обогащены полиядерными ароматическими УВ (ПАУ) (нафталины, фенантрены, пирены и т.д.) и их метилированными гомологами. В конденсате Радужных источников высоки концентрации 
Рис. 3 (начало)

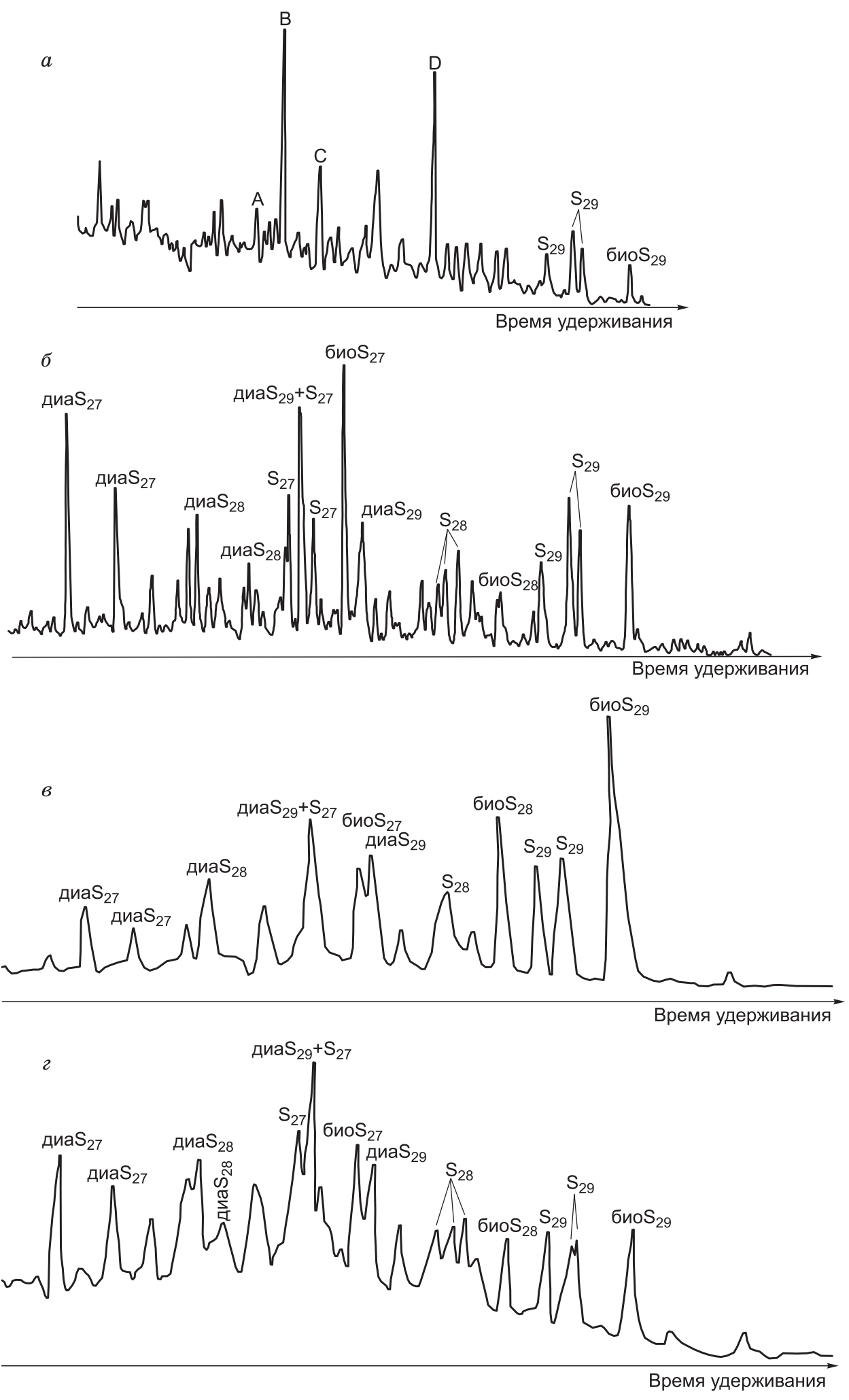

алкилбензолов [Clifton et al., 1990]. Из ароматических УВ в составе узонской нефти идентифицированы алкилбензолы и ароматические стероиды, а ПАУ не обнаружены [Simoneit et al., 2009; Конторович и др., 2011]. В бассейновых нефтях преимущественно встречаются моно-, би- и трициклические ароматические УВ [Конторович и др., 1973; Peters et al., 2005]. 


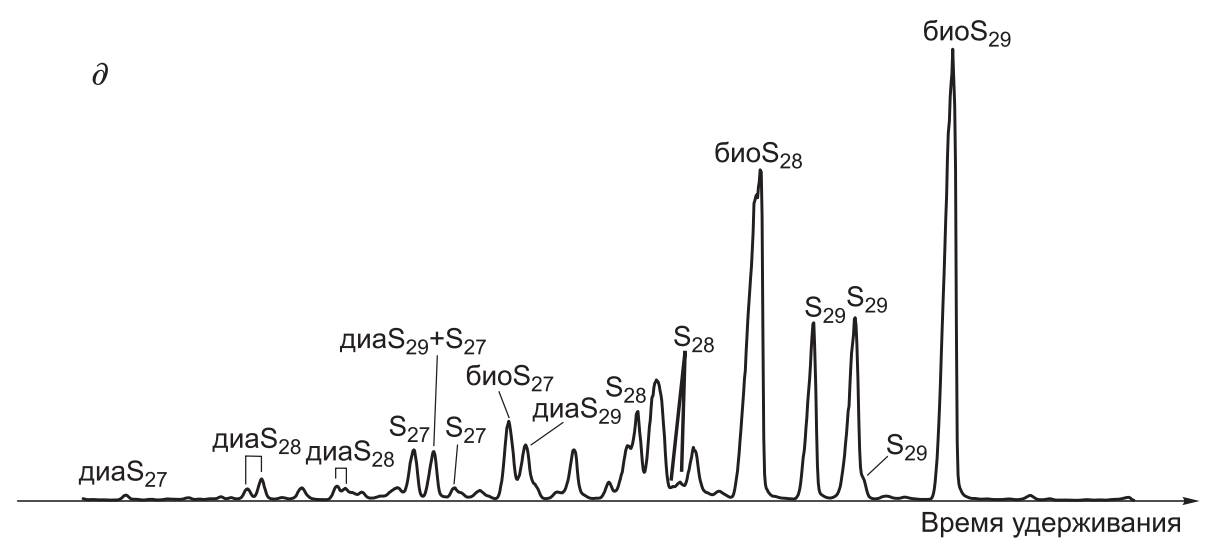

\section{Рис. 3. Масс-фрагментограммы стеранов $(m / z, 217)$, идентифицированных в насыщенной фракции нафтидов.}

$a-$ Радужные и $\sigma$ - Кальцитовые источники (Йеллоустоун); в - Вайотапу и $2-$ Нафа (Новая Зеландия); $\partial-$ кальдера влк. Узон (Камчатка). диа $\mathrm{S}_{27}$ - диа $\mathrm{S}_{29}$ - диастераны $(10 \alpha, 13 \beta, 17 \alpha, 20 \mathrm{R}$ и $20 \mathrm{~S})$; регулярные стераны: биоS ${ }_{27}$ биоS 29 - природные (био)

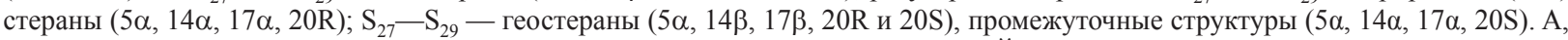
$\mathrm{B}, \mathrm{C}, \mathrm{D}$ - бикадинан и его изомеры. Масс-фрагментограммы стеранов нафтидов Йеллоустоуна и Новой Зеландии заимствованы из работ [Czochanska et al., 1986; Weston, Woolhouse, 1987; Clifton et al., 1990].

\section{ИСТОЧНИКИ, ЗРЕЛОСТЬ, ВТОРИЧНЫЕ ИЗМЕНЕНИЯ ГИДРОТЕРМАЛЬНЫХ НАФТИДОВ}

Источники УВ гидротермальных нафтидов. Состав УВ-биомаркеров в гидротермальных нафтидах указывает на полигенный состав живого вещества, из которого они образовались. Значительную роль в их формировании играли липидные компоненты высшей наземной растительности, фитопланктона, бактерий и, возможно, архей. Вероятно, часть органического материала в зонах гидротермального нефтеобразования попадала в осадки эоловым путем. Это могли быть, в частности, споры и пыльца. Нельзя исключать, что гидротермальные воды фильтровались через осадочные породы с органическим веществом морского и наземного генезиса и экстрагировали из них рассеянные углеводороды.

Подтвердим полигенную природу нафтидов конкретными данными («уликами», по Н.Б. Вассоевичу [1958]).

Распределение $\mu$-алканов в нафтидах Вайотапу и Кальцитовых источников имеет несколько максимумов $\left(\mathrm{C}_{16}, \mathrm{C}_{22}\right.$ и $\mathrm{C}_{18}, \mathrm{C}_{23}, \mathrm{C}_{29}$ соответственно), что свидетельствует об образовании этих компонентов за счет липидов как аквагенного, так и террагенного генезиса. В нефти Нафа максимум $н$-алканов смещен в высокомолекулярную область. Максимумы распределения $H$-алканов на $\mathrm{C}_{18}$ в нефтях Узона и Радужных источников указывают на более существенный вклад водорослевой органики по сравнению с восками высшей наземной растительности [Конторович и др., 1973; Конторович, 1976; Тиссо, Вельте, 1981; Peters et al., 2005]. Существенный вклад липидов фитопланктона в состав нефтей Узона и Вайотапу подтверждают низкие значения отношения пристан/фитан. На аквагенную природу части живого вещества (фитопланктон) - источника узонской нефти - указывают идентифицированные в составе насыщенной фракции 4-метилстераны - маркеры диатомей [Wolff et al., 1986; Peters et al., 2005], которые были описаны в работе [Конторович и др., 2011].

Вместе с тем имеются биогеохимические доказательства значительной роли липидов высшей наземной растительности в образовании нефтей Узона и Вайотапу (табл. 4). Среди стеранов в этих нефтях преобладают этилхолестаны $\left(\mathrm{C}_{29}\right)$, несколько меньше метилхолестанов $\left(\mathrm{C}_{28}\right)$, а холестаны $\left(\mathrm{C}_{27}\right)$ составляют не более $10 \%$ от суммы стеранов. Преобладание стеранов $\mathrm{C}_{29}$ в нефтях верхнего палеозоя, мезозоя и кайнозоя обычно рассматривают как признак генетической связи нефтей с липидными компонентами наземной растительности [Тиссо, Вельте, 1981; Петров, 1984; Конторович и др., 1991, 1999, 2011; Peters et al., 2005]. На террагенную природу органического вещества узонской нефти и йеллоустонского конденсата (Радужные источники) указывает также идентификация в составе их насыщенной фракции олеанана (см. рис. 4), предшественниками которого считаются терпеноиды покрытосемянных растений [Peters et al., 2005].

Высокие относительные концентрации низкомолекулярных трицикланов $\left(\mathrm{C}_{19}-\mathrm{C}_{20}\right)$ и их существенное преобладание над высокомолекулярными гомологами $\left(\mathrm{C}_{23}-\mathrm{C}_{26}\right)$, что отражает трициклановый 

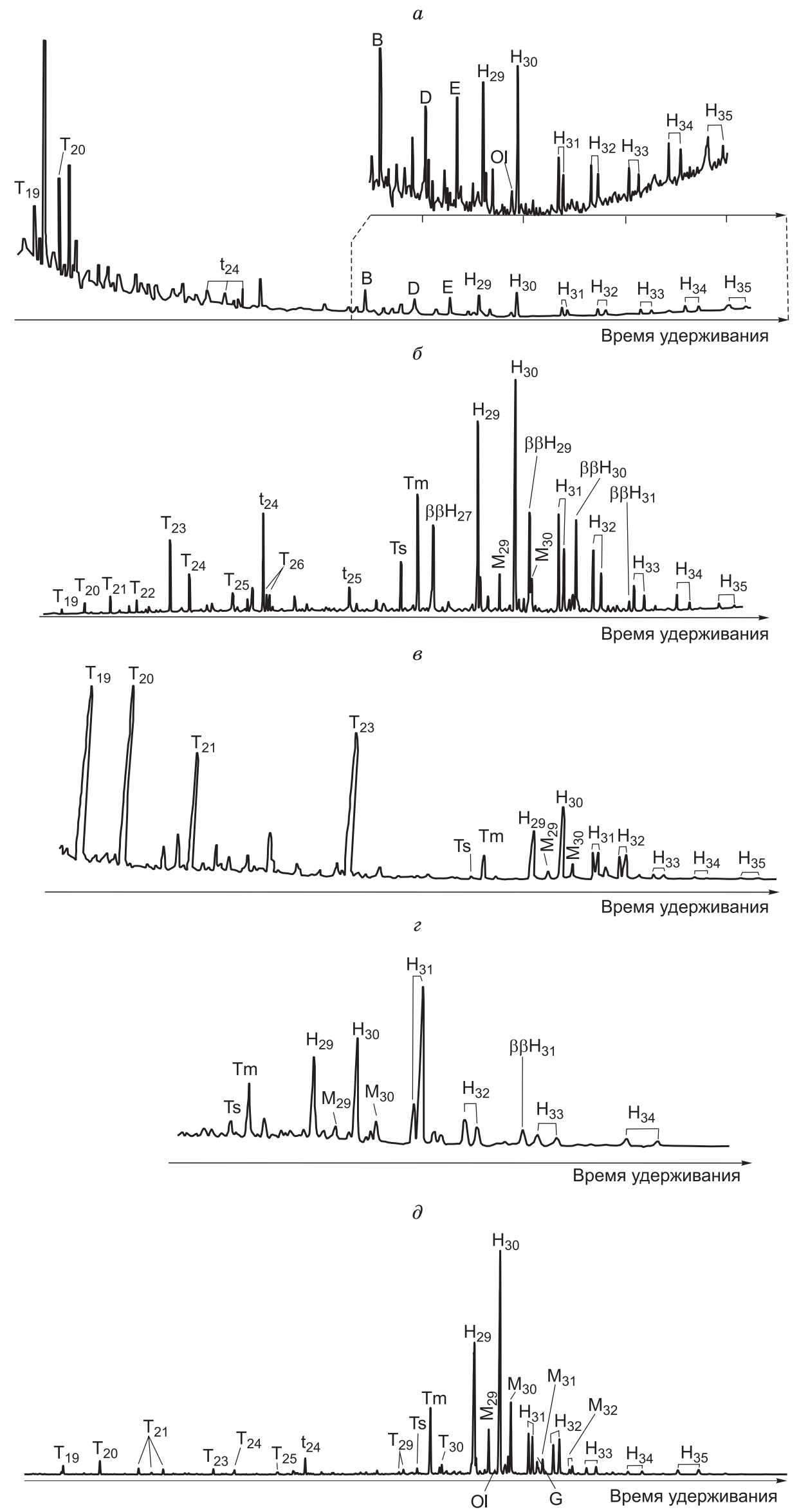

926 


\begin{tabular}{|c|c|c|c|c|c|c|c|c|c|}
\hline \multirow{3}{*}{\multicolumn{2}{|c|}{ Параметры по составу стеранов и терпанов }} & \multicolumn{8}{|c|}{ Локализация нафтидопроявления } \\
\hline & & \multirow{2}{*}{\multicolumn{2}{|c|}{ Узон, Камчатка }} & \multicolumn{3}{|c|}{$\begin{array}{c}\text { Кальцитовые источ- } \\
\text { ники } \\
\end{array}$} & $\begin{array}{c}\text { Радужные ис- } \\
\text { точники }\end{array}$ & Вайотапу & Нафа \\
\hline & & & & \multicolumn{4}{|c|}{ Йеллоустоун } & \multicolumn{2}{|c|}{ Новая Зеландия } \\
\hline \multirow{3}{*}{$\begin{array}{l}\text { Стераны } 5 \alpha 14 \alpha 17 \alpha, \\
\% \text { на } \sum \mathrm{C}_{27}-\mathrm{C}_{29}\end{array}$} & $\mathrm{C}_{27}$ & 8 & 8 & - & - & - & - & 9 & 41 \\
\hline & $\mathrm{C}_{28}$ & 35 & 41 & - & - & - & - & 29 & 24 \\
\hline & $\mathrm{C}_{29}$ & 57 & 51 & - & - & - & - & 62 & 35 \\
\hline \multicolumn{2}{|c|}{ Стераны $\mathrm{C}_{27} / \mathrm{C}_{29}(\alpha \alpha \alpha)$} & 0.14 & 0.15 & - & - & - & - & 0.15 & 1.15 \\
\hline \multicolumn{2}{|c|}{$\begin{array}{l}\text { Itc }=2 \cdot\left(\sum \text { хейлантанов } \mathrm{C}_{19}-\mathrm{C}_{20}\right) / \sum \text { хейлан- } \\
\left.\text { танов } \mathrm{C}_{23}-\mathrm{C}_{26}\right)\end{array}$} & 1.82 & 3.23 & - & - & - & - & - & - \\
\hline \multicolumn{2}{|c|}{ Адиантан/гопан $\mathrm{C}_{30}$} & 0.70 & 0.67 & & $0.82 *$ & & $0.83^{*}$ & 0.58 & 0.79 \\
\hline \multicolumn{2}{|c|}{ Моретан $\mathrm{C}_{30} /$ гопан $\mathrm{C}_{30}$} & 0.23 & 0.23 & & $0.13^{*}$ & & - & 0.22 & 0.21 \\
\hline \multicolumn{2}{|c|}{ Олеанан/гопан $\mathrm{C}_{30}$} & 0.01 & 0.01 & - & - & - & $0.15^{*}$ & - & - \\
\hline \multicolumn{2}{|l|}{ Стераны/гопаны } & 0.95 & 1.23 & 一 & - & - & 2.00 & - & - \\
\hline \multirow{2}{*}{$\begin{array}{l}\text { Изомерные соотно- } \\
\text { шения стеранов } \mathrm{C}_{29}\end{array}$} & $20 \mathrm{~S} /(20 \mathrm{~S}+20 \mathrm{R})(\alpha \alpha \alpha)$ & 0.15 & 0.20 & 0.37 & 0.38 & 0.37 & 0.52 & 0.24 & 0.45 \\
\hline & $\alpha \beta \beta /(\alpha \beta \beta+\alpha \alpha \alpha)(20 \mathrm{R})$ & 0.24 & 0.20 & 0.66 & 0.67 & 0.66 & 0.63 & - & - \\
\hline \multicolumn{2}{|l|}{$\mathrm{Ts} / \mathrm{Tm}$} & 0.08 & 0.08 & 0.42 & 0.41 & 0.41 & - & 0.14 & 0.29 \\
\hline \multicolumn{2}{|c|}{ Гопан $\mathrm{C}_{31} 22 \mathrm{~S} /(22 \mathrm{~S}+22 \mathrm{R})$} & 0.52 & 0.53 & & $1.50^{*}$ & & $1.53^{*}$ & 0.45 & 0.59 \\
\hline \multicolumn{2}{|c|}{ Гопан $\mathrm{C}_{32} 22 \mathrm{~S} /(22 \mathrm{~S}+22 \mathrm{R})$} & 0.46 & 0.46 & 0.58 & 0.59 & 0.59 & 0.59 & 0.92 & 0.20 \\
\hline
\end{tabular}

Примечание. Itc — трициклановый индекс. 1990].

* Рассчитано авторами по высотам пиков в масс-фрагментограммах, опубликованных в работе [Clifton et al.,

индекс, являются еще одним признаком террагенного генезиса нефтематеринского вещества нефтей Узона и Вайотапу [Конторович и др., 1999; Peters et al., 2005]. На значительную роль липидов высшей наземной растительности в образовании этих нефтей указывают также относительно высокие концентрации в них изотопа углерода ${ }^{13} \mathrm{C}$ (значения $\delta^{13} \mathrm{C}$ составляют в среднем $-28 \%$ ).

Иной состав имеет нефть Нафа и мальты Кальцитовых источников. В этих нафтидах преобладают холестаны и мало этилхолестанов (см. рис. 3), что характерно для нафтидов, генетически связанных с липидами фитопланктона и бактерий.

Как отмечалось выше, в мальтах Кальцитовых источников и в нефти гидротерм Нафа близки концентрации диастеранов и регулярных стеранов. Считается, что диастераны образуются при катагенезе из диастеренов - диагенетических продуктов каталитической конверсии стеролов в присутствии глинистых минералов (монтмориллонит, иллит) [Peters et al., 2005]. Следовательно, можно предполагать, что насыщенные углеводороды нафтидов с высокими концентрациями диастеранов образовались из органического вещества, захороненного в морских терригенных (глинистых) осадках.

Значительное участие террагенного органического вещества в образовании конденсата Радужных источников подтверждают высокие концентрации бикадинана и его изомеров, идентифицированных на масс-фрагментограммах по m/z 217 и 191 (см. рис. 3) [Clifton et al., 1990]. Считается [van Aarsen et al., 1990; Armanios et al., 1995; Peters et al., 2005], что бикадинаны новообразуются при термокаталитическом преобразовании поликадиненов - полимерных соединений смол высшей наземной растительности.

Наиболее вероятным источником ПАУ в мальтах Кальцитовых источников является органическое вещество, унаследованное от высшей наземной растительности [Конторович и др., 1973; Тиссо, Вельте, 1981; Peters et al., 2005].

Рис. 4. Масс-фрагментограммы терпанов (m/z 191$)$, идентифицированных в насыщенной фракции нафтидов.

$a-\partial-$ см. на рис. $3 . \mathrm{T}_{19}-\mathrm{T}_{30}$ - трициклические терпаны - хейлантаны; $\mathrm{t}_{24}, \mathrm{t}_{25}$ - тетрациклические терпаны; Tm - $17 \alpha(\mathrm{H})$ $22,29,30$-трисноргопан; Ts - $18 \alpha(\mathrm{H}) 22,29,30$-триснорнеогопан; $\mathrm{H}_{29}-\mathrm{H}_{35}$ - гопаны и гомогопаны $(17 \alpha 21 \beta) ; \beta \beta \mathrm{H}_{27}-\beta \beta \mathrm{H}_{31}-$

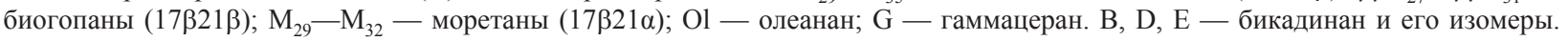
Остальные усл. обозн. см. на рис. 3. 
Уровень катагенетической преобразованности нафтидов. Уровень зрелости гидротермальных нафтидов различается, но в целом он ниже, чем у большинства бассейновых нефтей.

На ранние стадии катагенеза нефтематеринского органического вещества гидротермальных нафтидов указывает соотношение в них $\mu$-алканов с нечетным и четным количеством атомов углерода в цепи (индекс CPI) (см. табл. 3) [Bray, Evans, 1961; Philippi, 1965]. Этот показатель имеет значения выше единицы в конденсате Радужных источников и в мальтах Кальцитовых источников. В мальтах Кальцитовых источников распределение высокомолекулярных $\mu$-алканов с нечетным и четным количеством атомов углерода в молекуле имеет пилообразный характер (см. рис. 3). По индексу СРІ, близкому 1, нефти Узона и Новой Зеландии следует относить к зрелым (см. табл. 3).

Четким индикатором уровня катагенетической преобразованности ОВ считается соотношение норгопанов Ts и Tm [Peters et al., 2005]. По значениям этого показателя наименее зрелой является нефть кальдеры влк. Узон, далее следуют гидротермальные нефти Новой Зеландии, а наиболее катагенетически преобразованными являются мальты Кальцитовых источников.

На низкую зрелость рассматриваемых гидротермальных нефтей указывает также изомерный состав стеранов [Петров, 1984; Peters et al., 2005]. По соотношению стереоизомеров стеранов нефти Узона и Новой Зеландии существенно отличаются от бассейновых нефтей. Это хорошо иллюстрируют массфрагментограммы по $\mathrm{m} / z 217$ (см. рис. 3): в них повышены содержания «биологических» структур (5 $\alpha$, $14 \alpha, 17 \alpha, 20 \mathrm{R}$ стераны), что является одним из признаков их слабой катагенетической трансформации. Самый низкий уровень преобразованности «биологических» стеранов имеет место в узонской нефти (см. табл. 4). По значениям стерановых показателей нафтиды Йеллоустоуна и Новой Зеландии термически более преобразованы, чем узонские. Об этом же может свидетельствовать тот факт, что в нафтидах Йеллоустоуна и Вайотапу значительно больше концентрации хейлантанов по сравнению с нефтью Узона.

Присутствие $\beta \beta$ гопанов в нафтидах Кальцитовых источников и Нафа находится в противоречии с выводом о более высоком уровне их зрелости, основанном на анализе распределения терпанов и стеранов, по сравнению с другими рассматриваемыми гидротермальными нефтями. Их наличие авторы работ [Czochanska et al., 1986; Clifton et al., 1990] объясняют возможной экстракцией близповерхностной бактериогенной органики гидротермальным потоком, выносящим нефти на поверхность.

Вторичные превращения нефтей. Биодеградация. Несмотря на невысокий уровень катагенетической преобразованности изученных гидротермальных нафтидов в них проявляются признаки вторичных изменений, в первую очередь, окисления и биодеградации. В качестве свидетельств этих процессов можно рассматривать высокие содержания смол и асфальтенов в нефти Вайотапу и в мальтах Кальцитовых источников и одновременно низкие концентрации в них насыщенных и высокие - ароматических углеводородов.

Нафтиды Кальцитовых источников по соотношению углеводородных и полярных фракций являются мальтами (природными продуктами гипергенного преобразования нефтей), но в них присутствуют $H$-алканы, которые обычно подвергаются биодеструкции в первую очередь. Можно предполагать, что $H$-алканы в составе этих нафтидов образовались при попадании липидосодержащих продуктов в источники позднее первой фазы гипергенных (биодеградация) процессов.

В нефтях Узона и Вайотапу повышены отношения пристана и фитана к $н$-алканам, соответствующим им по времени элюирования (н-С $\mathrm{C}_{17}$ и $н$ - $\mathrm{C}_{18}$ соответственно) (см. рис. 2, табл. 3), что может быть следствием начальных стадий биодеградации [Pirnik et al., 1974; Петров, 1984; Peters et al., 2005]. Наличие интенсивных пиков на хроматограмме насыщенной фракции узонской нефти, относящихся к стеранам и терпанам (см. рис. 2), может рассматриваться как свидетельство остаточного накопления стеранов при частичной биодеградации насыщенных УВ.

Рассматриваемые нафтиды находятся на очень ранней стадии биодеградации, так как в них высоки концентрации $\boldsymbol{H}$-алканов, а в распределении УВ-биомаркеров отсутствуют признаки существенного микробиального окисления (например, присутствие в составе терпановой фракции деметилированных 25-норгопанов) [Петров, 1984; Конторович и др., 1991; Peters et al., 2005]. Специфика распределения УВ-биомаркеров в них отражает, в первую очередь, генетические особенности нефтематеринского ОВ.

\section{ЗАКЛЮЧЕНИЕ}

Наличие в рассматриваемых гидротермальных нафтидах широкого спектра УВ-биомаркеров и изотопный состав углерода указывают, что их источником являлись липиды живого вещества. Судя по составу УВ-биомаркеров, гидротермальные нефти и мальты по источнику липидов, из которых они образовывались, имеют полигенную природу. Источником большинства нафтидов являлись липиды высшей наземной растительности. УВ, источником которых были липиды водорослевого ОВ, присутствуют в меньших концентрациях. Уникальным для нефтей является наличие в нефти кальдеры влк. Узон 
коротокоживущего изотопа углерода ${ }^{14} \mathrm{C}$. Имеющаяся информация по концентрации изотопа ${ }^{14} \mathrm{C}$ показала очень молодой возраст узонской нефти - около 1000 лет [Simoneit et al., 2009].

Анализ состава УВ гидротермальных нафтидов показывает, что:

- основным источником нафтидов Йеллоустоуна были липиды высшей наземной растительности и простейших водорослей с возможной незначительной примесью бактериогенной органики;

- нефти Новой Зеландии образовались за счет липидов высшей наземной растительности и простейших водорослей;

- источником нефти Узона являются липиды высшей наземной растительности, озерных водорослей и бактерий.

Изученные гидротермальные нафтиды имеют низкий и умеренный уровень катагенетической преобразованности.

Несмотря на молодой возраст, некоторые из гидротермальных нефтей подверглись вторичным изменениям (испарение, окисление, биодеградация).

Общим для рассмотренных нафтидов является их образование в условиях приповерхностных гидротерм. Преобразование липидов живого вещества в УВ в таких геологических условиях происходит не за счет постепенного возрастания температуры осадочных пород при их погружении на значительные глубины (бассейновые нефти), а за счет повышенных температур в гидротермальных системах.

Таким образом, гидротермальные источники являются природными лабораториями, в которых в современную геологическую эпоху реализуется один из путей преобразования липидов живого вещества в нефти.

Работа выполнена при поддержке междисциплинарного интеграционного проекта фундаментальных исследований СО РАН № 93 «Изучение биологии, биохимии и геохимии живого и ископаемого вещества и нефтей в районах современных гидротермальных проявлений, оценка роли в нефтеобразовании ювенильного вещества».

\section{ЛИТЕРАТУРА}

Бескровный Н.С., Лебедев Б.А. Нефтепроявление в кальдере вулкана Узон на Камчатке // Докл. АН СССР, 1971, т. 201, № 4, с. 953-956.

Вассоевич Н.Б. Образование нефти в терригенных отложениях (на примере чокракско-караганских слоев Терского передового прогиба) // Вопросы образования нефти. Л., Гостоптехиздат, 1958, с. 9 220. (Тр. ВНИГРИ, вып. 128).

Геология нефти и газа Сибирской платформы / Под ред. А.Э. Конторовича, В.С. Суркова, А.А. Трофимука. М., Недра, 1981, 552 с.

Добрянский А.Ф. Геохимия нефти. Л., Гостоптехиздат, 1948, 477 с.

Калинко М.К. Генезис микронефтепроявлений кальдеры вулкана Узон (Восточная Камчатка) // Преобразование органического вещества в современных и ископаемых осадках и основные этапы генерации свободных углеводородов. М., ВНИГНИ, 1975, с. 50-58. (Тр. ВНИГНИ, вып. 175).

Карпов Г.А. Современные гидротермы и ртутно-сурьмяно-мышьяковое оруденение. М., Наука, 1988, 183 c.

Конторович А.Э. Геохимические методы количественного прогноза нефтегазоносности. М., Недра, 1976, 250 с. (Тр. СНИИГГиМСа, вып. 229).

Конторович А.Э., Бабина Н.М., Данилова В.П., Зуева Т.В., Мельникова В.М. Полиядерные ароматические углеводороды рассеянного органического вещества // Геология и геофизика, 1973 (9), c. $84-91$.

Конторович А.Э., Петерс К.Е., Молдован Дж.М., Андрусевич В.Е., Демейсон Д.Дж., Стасова О.Ф., Хьюзинге Б.Дж. Углеводороды-биомаркеры в нефтях Среднего Приобья (Западная Сибирь) // Геология и геофизика, 1991 (10), с. 3-34.

Конторович А.Э., Бахтуров С.Ф., Башарин А.К., Беляев С.Ю., Бурштейн Л.М., Конторович А.А., Кринин В.А., Ларичев А.И., Ли Году, Меленевский В.Н., Тимошина И.Д., Фрадкин Г.С., Хоменко А.В. Разновозрастные очаги нафтидообразования и нафтидонакопления на Северо-Азиатском кратоне // Геология и геофизика, 1999, т. 40 (11), с. 1676-1693.

Конторович А.Э., Бортникова С.Б., Карпов Г.А., Каширцев В.А., Костырева Е.А., Фомин А.Н. Кальдера вулкана Узон (Камчатка) - уникальная природная лаборатория современного нафтидогенеза // Геология и геофизика, 2011, т. 52 (8), с. 986-990.

Орлов Н.А., Успенский В.А. Минералогия каустобиолитов. М., Изд-во АН СССР, 1936, 198 с.

Петров Ал.А. Углеводороды нефти. М., Наука, 1984, 263 с. 
Тиссо Б., Вельте Д. Образование и распространение нефти. М., Мир, 1981, 502 с.

Успенский В.А., Радченко О.А., Глебовская Е.А., Горская А.И., Шишкова А.П., Парпарова Г.М., Колотова Л.Ф., Мельцанская Т.Н. Основы генетической классификации битумов. Л., Недра, 1964, 266 с. (Тр. ВНИГРИ, вып. 23).

van Aarssen B.G., Cox H.C., Hoogendoorn P., De Leeuw J.W. A cadinene biopolymer in fossil and extant dammar resins as a source for cadinanes and bicadinanes in crude oils from South East Asia // Geochim. Cosmochim. Acta, 1990, v. 54, p. 3021-3031.

Armanios C., Alexander R., Sosrowidjojo I.B., Kagi R.I. Idenification of bicadinanes in Jurassic organic matter from the Eromanga Basin, Australia // Org. Geochem., 1995, v. 23, № 9, p. 837—843.

Bazhenova O.K., Arefiev O.A., Frolov E.V. Oil of the volcano Uzon caldera, Kamchatka // Org. Geochem., 1998, v. 29, № 1-3, p. 421-428.

Brault M., Simoneit B.R.T., Marty J.C., Saliot A. Hydrocarbons in waters and particulate material from the hydrothermal environments at the East Pacific Rise, $13^{\circ} \mathrm{N} / /$ Org. Geochem., 1988, v. 12, p. 209-219.

Bray E.E., Evans E.D. Distribution of $n$-paraffins as a clue to recognition of source beds $/ /$ Ceochim. Cosmochim. Acta, 1961, v. 22, № 1, p. 2-15.

Clifton C.G., Walters C.C., Simoneit B.R.T. Hydrothermal petroleums from Yellowstone National Park, Wyoming, USA // Appl. Geochem., 1990, v. 5, p. 169-191.

Czochanska Z., Sheppard C.M., Weston R.J., Woolhouse A.D., Cook R.A. Organic geochemistry of sediments in New Zealand. Part I. A biomarker study of the peteroleum seepage at the geothermal region of Waiotapu // Geochim. Cosmochim. Acta, 1986, v. 50, p. 507-515.

Kawka O.E., Simoneit B.R.T. Survey of hydrothermally-generated petroleums from the Guaymas Basin spreading center // Org. Geochem., 1987, v. 11, p. 311-328.

Kvenvolden K.A., Simoneit B.R.T. Hydrothermally derived petroleum: examples from Guaymas Basin, Gulf of California and Escanaba Trough, northeast Pacific Ocean // AAPG Bull., 1990, v. 74, p. 223-237.

Peters K.E., Walters C.C., Moldowan J.M. The biomarker guide. 2nd ed. New York, Cambridge University Press, 2005, $1621 \mathrm{p}$.

Philippi G.T. On the depth, time and mechanism of petroleum generation // Geochim. Cosmochim. Acta, 1965, № 29, p. 1021-1049.

Pirnic M.P., Atlas R., Bartha R. Hydrocarbon metabolism by Brevibacterium erythrogenes: normal and branched alkanes // J. Bacteriology, 1974, № 119, p. 868 - 878.

Simkin T., Tilling R.I., Vogt P.R., Kirby S.H., Kimberly P., Stewart D.B. This dynamic planet — interpretive map. 2006. http://www.volcano.si.edu/tdpmap/fom/interpretive.cfm.

Simoneit B.R.T. Aqueous high-temperature and high-pressure organic geochemistry of hydrothermal vent systems // Geochim. Cosmochim. Acta, 1993, v. 57, p. 3231-3243.

Simoneit B.R.T., Lonsdale P.F. Hydrothermal petroleum in mineralized mounds at the seabed in Guaymas Basin // Nature, 1982, v. 295, p. 198-202.

Simoneit B.R.T., Deamer D.W., Kompanichenko V. Characterization of hydrothermally generated oil from the Uzon caldera, Kamchatka // Appl. Geochem., 2009, v. 24, p. 303-309.

Weston R.G., Woolhouse A.D. Organic geochemistry of the sedimentary basins of New Zealand. Part IV. A biomarker study of the petroleum seepage and some well core bitumens from the geothermal region of Ngawha Springs // Appl. Geochem., 1987, v. 2, p. 305-319.

Wolff G.A., Lamb N.A., Maxwell J.R. The origin and fate of 4-methyl steroid hydrocarbons. I. Diagenesis of 4-methyl sterenes // Geochim. Cosmochim. Acta, 1986, v. 50, № 3, p. 335-342. 